\title{
A Sociology of Archetypes
}

Mike Sosteric

mikes@athabascau.ca

Version 0.96

Word Count: 8,286 


\begin{abstract}
Archetypes are primordial and collective images of spiritual/psychic/instinctual power. Archetypes inform our self-image, influence how we see the world, and direct many of the actions we take as we navigate and create our realities. According to psychologist Carl G. Jung, archetypes are powerful determines of human experience and human psychological and political realities. As such, they hold significant spiritual, psychological, and sociological interest. There has been sustained interest from those interested in the psychology and spirituality of archetypes; however to date sociologists have remained largely aloof. Hoping to overcome this lacuna, this paper explores the sociology of archetypes by examining the emotional and psychological power of archetypes and by demonstrating how powerful archetypes become situated in elite "spiritual" discourses designed not in the service of human health and development, but in the service of the political and economic agenda of societal and world elites.
\end{abstract}

Keywords: Archetypes, Jung, Religion, Freemasonry, Tarot 
The ideas of the ruling class are in every epoch the ruling ideas, i.e. the class which is the ruling material force of society, is at the same time its ruling intellectual force. The class which has the means of material production at its disposal, has control at the same time over the means of mental production, so that thereby, generally speaking, the ideas of those who lack the means of mental production are subject to it.....Insofar, therefore, as they rule as a class and determine the extent and compass of an epoch, it is self-evident that they do this in its whole range, hence among other things rule also as thinkers, as producers of ideas, and regulate the production and distribution of the ideas of their age: thus their ideas are the ruling ideas of the epoch. (Marx 1978:172).

...in any society, there are manifold relations of power which permeate, characterise and constitute the social body, and these relations of power cannot themselves be established, consolidated nor implemented without the production, accumulation, circulation and functioning of a discourse.... We are subjected to the production of truth through power and we cannot exercise power except through the production of truth. (Foucault 1980:93)

It is therefore possible to contribute to political action not only by entering the fray but also by providing studies of official techniques of regulation, punishment, normalisation and so on to those groups which have a direct interest in their subversion” (McHoul and Grace 1993:19) 


\section{Introduction}

Samuel Perry notes that sociologists are not always self-reflective of their own understandings of religious artifacts like the bible (Perry 2020). Perry suggests sociologists approach the bible with a "protestant bias" and assume it is uniform, static, and exogenous, meaning the text remains a static object originating outside contemporary interpretative communities. As Perry notes, this is not so. He provides an analysis of the Christian bible that demonstrates how its meanings and even its text are contested and altered, sometimes in dramatic ways, to suit the particular agenda of various contemporary actors with the power to alter the text.

The contemporary bible is not the only location where interpretive communities fiddle with and alter the meaning of spiritual texts. According to Ehrman (2007), representatives of the Catholic Church entered thousands of edits into the original bible, many of which it would be safe to assume supported the elite and patriarchal prerogatives of the Medieval Catholic church. Similarly, Sosteric (2014) examines how elite political actors constructed an entire spiritual discourse around a common pack of Italian playing cards, a discourse that was aimed at 
controlling how people think, feel, and act, in service to their Capitalist political and economic agenda.

These sorts of analysis are important, particularly given the significance of religion and religious meaning to human behaviour and the economic and political landscapes they construct (Glass 2019). Nevertheless, sociologists have tended to shy away from such analysis. As Glass notes, “...there has been too much emphasis on the organizational practices of religions rather than how religions affect other organizations' practices! And there has been too little investigation of how individual religious beliefs and practices affect interactions and outcomes within organizations, including educational, legal, political, and occupational.” (Glass 2019:23)

In this paper, I want to examine another aspect of human spirituality and religion where interpretive communities manipulate religious meaning in support of specific agendas, thereby impacting reality, and that is archetypes. Archetypes are psychological constructs and typically not used by sociologists to understand religion, but they should be. Archetypes are the core symbolic representations of mystical/religious experience. As such, archetypes provide the foundational symbolic grammar upon which powerful and often destructive (Ellens 2001) religious belief systems are built. When we think of typical religious constructs like good versus evil, the soul's redemption, the hero's spiritual journey through life, and so on, we are thinking about, and thinking with, archetypes. Typically, archetypes are seen as natural expression of 
human consciousness or instincts. However, as this paper will demonstrate, archetypes though they may originate in human consciousness are not solely the product of said consciousness. Other factors, and other actors, impact the construction and distribution of these powerful elements of human consciousness.

\section{What are archetypes?}

The first step forward in our examination of archetypes is to define what is an archetype exactly? According to Carl Jung, an archetype is a collectively shared symbolic representation of some of idea or concept (Jung 1964, 1980). I would define archetypes as simply ideas that provides answers to big questions, like "Who am I?" and "What is my purpose?" A common example of an archetype is the Hero archetype (Campbell 2008). The Hero archetype is an archetype that, according to Joseph Campbell, tells us the story of the human journey through life. According to the archetype, on this journey, the individual must past tests and challenges. A successful hero's journey leads to self-realization, individuation, or some other psychological reward. An unsuccessful journey leads to psychological collapse, selfishness, or some other negative psychological or emotional outcome.

Archetypes are interesting to psychologists and others interested in human spirituality for at least

four reasons. Number one, as Jung, Campbell, and others have observed, archetypes appear in 
roughly the same form in the experiences of adults and children all over the world. They are, in short, universal features of human experience that remain identifiable despite their historical or cultural context. For scholars and others interested in human psychology and human spirituality, the existence of these universal features of experience point to deep psychological, perhaps even spiritual, processes that underlie our human existence.

The second reason that archetypes are interesting is because their experience, especially during powerful mystical experiences, is often attended by psychological and emotional healing, even transformation (Miller 2004; Vaillant 2002). Archetypes are not merely random outbursts of an over imaginative psyche; they bear considerable psychological and emotional weight. According to Jung, archetypes function to facilitate individuation (i.e. mental and emotional maturation) and healing. Carl Jung said archetypes help us understand things we cannot understand, deal with realities (like death) that we would rather not deal with, and add meaning to an otherwise meaningless existence. Archetypes provide "mental therapy for the sufferings of anxieties of [humankind] in general [like] hunger, war, disease, old age, death.” (Jung 1980:11). This Jungian perspective on archetypes has triggered a significant psychological literature on using archetypes found in various "sacred" sources for psychological and spiritual development (Jayanti 1988; Metzner 1971; Semetsky 2000) 
The third reason archetypes are interesting is because, as Jung recognized, archetypes are powerful, so powerful in fact that archetypes shape reality. They underlie and "create myths, religion, and philosophies that influence and characterize whole nations and epochs of history." (Jung 1964:76). We can see the power and influence that archetypes have if we consider the good versus evil archetype. This archetype, which postulates a cosmic/evolutionary struggle between forces of good and evil, is adopted by atheists, agnostics, and devotees the world over. These forces may be personified into powerful cosmic forces, like Satan or Darth Vader, or they may be secularized as powerful and unconscious psychological or instinctual structures (Regardie 2004), like Jung's Shadow and Animus or Freud's selfish little id. Many individuals adopt some version of this archetype and when they do, it exerts a powerful influence on their lives. It influences how they see the world, how they seem themselves, and how they act in the world. Those who adopt this archetype inevitably see themselves to one degree or another as actors on the side of good in some cosmic struggle against evil. They also inevitably see the operation of these forces in the world. Nazi Germany? School shootings? Taliban oppression? American Imperialism? Monsanto greed? The fall of New York's twin towers? When we adopt the good versus evil archetype, we see in these events the operation of evil. Finally, those who adopt the good versus evil archetype act a certain way towards others. Those we think of as "evil" get rejection, disdain, and even physical violence. Those who are deemed as good get to be included and supported within the community. 
Why do archetypes exert this power over individuals? It is not because of mystical or magical power, but simply because these archetypes seem to provide sacred answers to our existential imperatives. Existential imperatives are big questions about our origin, purpose, and path in life. These imperatives include questions like "Why am I here?", "What is my purpose?" or "Why do bad things happen in the world?" Archetypes are powerful because they provide ready made sacred-seeming answers to life's vital big questions, answer which when adopted influence the thinking and actions of those who adopt them. For example, the good versus evil archetype answers at least three big questions for people, "Why am I here?" "What is my purpose" and "Why do bad things happen to people?" The answer the good versus evil archetype provides is that bad things in the world happen because of evil, either internalized as a part of flaws in your identity, or personified as an external force. Your purpose for existence, your reason for being here, is to choose good so you can fight against, and ultimately destroy, all that is evil.

Another example of an archetype that exerts incredible power on the human psyche and human action is, as introduced briefly above, the so-called "hero" archetype (Campbell 2008). Like the good versus evil archetype, this archetype answers the big questions "Why am I here?" and "What is my purpose?" The answer it provides is that you are here to respond to a "calling" so that you can go on a "dangerous journey of the soul," a lifetime (even multi-lifetime) journey of self-discovery, enlightenment, testing, struggle, evolution, and final perfection (Campbell 2008). As one pair of authors note as they discuss the goal of the journey, "...perfection is indeed the 
goal of every human life but that it may take many lifetimes to achieve...Failing to reach full realization in this life doesn't damn you to perdition; it simply means you'll have to come back again and again until you get it right" (Smoley and Kinney 2006).

This Hero archetype is present everywhere. You find this idea in Western theology (you are ejected from the Garden and you have to win your way back in), Eastern theology (in order to reach Nirvana you have to learn lessons and clear any karmic debt you accumulate), and science where you are considered an evolving ape moving towards higher levels of capacity and consciousness. You also find it peppered in the art and cultures of this world. You find it in movies, music, television, literature, news, and so on. It is even configured into the Western Tarot by the Fool card, which shows an individual "hero" (here redefined as a "fool') about to step off mountain to undertake a herculean journey towards perfection. To tell the full story, this fool is jumping into a body (a "chariot", another tarot card) and his body is going to carry him through a lifetime of divine or evolutionary lessons where he will, if he is lucky, pass judgment (another tarot archetype), enter into heaven, graduate onto the next universal level, and so on and so forth. He is a "fool in school" and according to this pervasive archetype, so are you. Tarot connoisseur Brigit Biddy perfectly captures the story.

In the Fool Tarot card, a young man stands on the edge of a cliff, without a care in the world, as he sets out on a new adventure. He is gazing upwards toward the sky 
(and the Universe) and is seemingly unaware that he is about to skip off a precipice into the unknown. Over his shoulder rests a modest knapsack containing everything he needs - which isn't much (let's say he's a minimalist). The white rose in his left hand represents his purity and innocence. And at his feet is a small white dog, representing loyalty and protection, that encourages him to charge forward and learn the lessons he came to learn. The mountains behind the Fool symbolise the challenges yet to come. They are forever present, but the Fool doesn't care about them right now; he's more focused on starting his expedition.(Brigit 2020: italics added) 


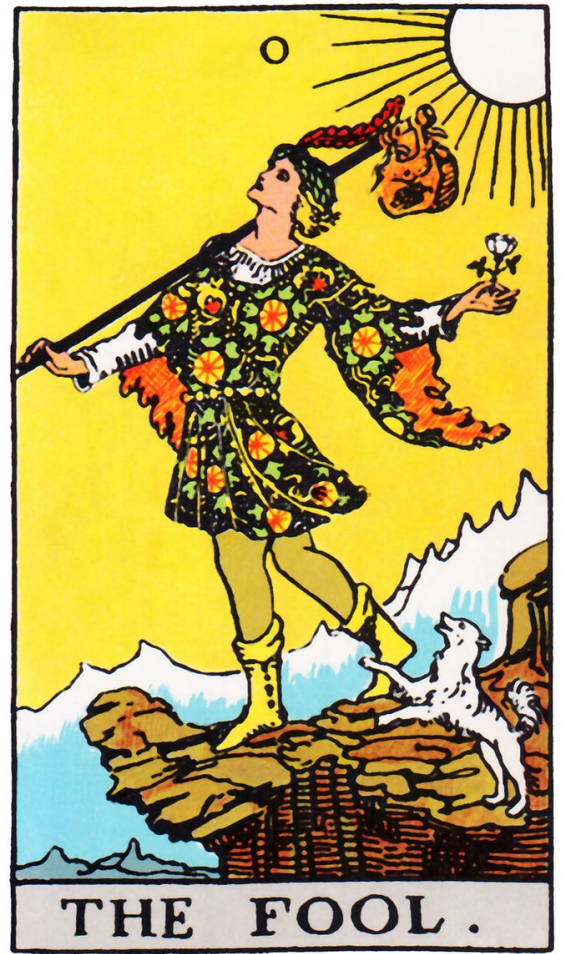

As with the good versus evil archetype, the fool archetype influences how people see themselves, how they see the world, and how they act in it as well. Those who adopt this archetype will see their life as a school where their "sacred" task is to learn all its lessons. They will also act according to the logic embedded within. If an unfortunate event occurs (say they get cancer) they will look for the lesson in the event, perhaps even ignoring the real cause of the cancer (like corporate effluent in their water supply). If something good happens, they will interpret it as karmic or evolutionary reward for good behaviour and ignore any of the social class conditions 
or privileges that went into its manifestation. Either way, their interpretation of events, their view of self, and the actions they take in the world, will be influenced by the Fool in School archetype.

\section{Where do archetypes come from?}

Arguably, archetypes are significant and important. The question at this point becomes, where do archetypes come from? First and foremost, archetypes come from the human imagination. For an archetype to exist, it must be imagined in some way. There are different ways people imagine archetypes. Sometimes archetypes emerge in gentle meditative states. Sometimes they emerge in dreams with deep meaning. Sometimes they occur in powerful "mystical" visions. Note that this imagining of archetypes is not uncommon. Many, perhaps all, people have archetypal experiences at one point or another in their life. We find archetypal elements in the dreams of children (Jung 1964), in the Dreamtime of Australian aborigines (Lawlor 1991; Mudrooroo 1995), in the dream quests, vision quests and power quests of Indigenous North Americans (Broker 1983; Frederick Johnson 1943; Harner 2013), in the mystical experiences of Christian mystics (Jantzen 1995; Julian of Norwich 1901), and in the output of artists like Michelangelo or Pink Floyd (for example their The Wall album has overtones of the Hero's Journey).

Not all the things that occur in your brain, not all ideas that come from human imagination, not all ideas expressed with human hands, qualify as archetypes. Most ideas, even if those ideas are 
ideas that answer big questions, are merely ideas; few ever rise to the status of archetype. So, what qualifies an idea as an archetype? Jung says archetypes have a "specific energy" (Jung 1964). They feel special and contain a "peculiar fascination." We might say archetypes have an intellectual and emotional valence that normal ideas do not. This is most certainly true. Anybody who has ever experienced an archetypal vision or dream knows these imaginings feel different than normal thought.

It is accurate to suggest that archetypes are sourced in human imagination and underlined by special experiences, but this does not get to their root. The question remains, where does human imagination come from? There are two possible answers to this question. The first answer is that imagination (and the archetypes which flow from it) are rooted in the neurological and biological systems of the body. In this materialist view, it is the neurons in your brain that form the substrate from which emerge the images, words, and music that form our archetypal representations. Along these lines, Carl Jung suggested archetypes were "archaic remnants" or "primordial images of our primordial human experiences, present in an "immensely old psyche" that still forms the basis of our modern mind (Jung 1964). He suggested these primordial ideas are expression of our "instincts" and "physiological urges" that "manifest themselves in fantasies and often reveal their presence only by symbolic images " (Jung 1964). They are "the unconscious image of the instincts themselves, in other words...they are patterns of instinctual behaviour." (Jung 1980:44: italics in original). According to Jung, archetypes represent the way 
our primitive, but curiously more powerful, unconscious mind "thinks;" as Jung says, archetypes, as representations of a powerful symbolic unconsciousness, "paves the way for solutions" (Jung 1980:33) to issues, fear, problems, etc. More recently, but in the same Jungian line of thought, evolutionary psychologists and neurologists have suggested that archetypes are "core representations of social instincts" (Vaughn and Neuberg 2019) that arise as a consequences of the challenges our ancient ancestors faced. As Becker and Neuberg note (2019:61), "Archetypes arise from complex adaptive systems that have been selected to solve social and biological problems."

Jung and others go through quite a few contortions to get to a point where it might be reasonable to claim that the collective, creative, meaningful, and powerful archetypes that emerge are adaptive components of the body's neurological systems. However, if one is prepared to put aside materialist presumptions it is possible to suggest an alternative, that archetypes are conceptual/symbolic communications from a Consciousness that exists independent of the individual human mind and body, from a non-local mind as Dossey (2015) suggests, or a Fabric of Consciousness, as I would suggest. Connection to this independent consciousness is variable and not a given. Most of the time we are closed to communication with this Fabric; however, during the periods of receptivity and connection that occur in dreams, during quiet meditative practice, and in powerful and visionary experiences, the contents of this Fabric filter (sometimes 
slam) their way through. When they do, they are interpreted as special/sacred ideas/archetypes by the people who experience them.

The question of the ultimate source of archetypes, whether these originate in bodily systems or are transmitted and received from some larger independent source, is important, but beside the point here. For our purposes, it is enough to understand that the human imagination is the proximate source of archetypes. It is when a human imagines something in a dream, a vision, or whatever, and it is when these dreams and images contain collectively significant psychological, emotional, or intellectual messaging, that we see the manifestation of an archetype.

\section{Symbol Factories}

Typically, the psychological/neurological story about archetypes ends with the assertion that the archetypes are biologically rooted adaptive messages of some sort. The psychological task then becomes to show how these adaptions link to psychological, sociological, or evolutionary pressures. However, from a sociological perspective, it is important to understand archetypes are not just individual productions. When a child, an adult, a mystic, a dying person, or whatever, has a vision, and when that vision contains a powerful archetype, that person is rarely the only one involved in that vision. As noted, archetypes, when they emerge in individual consciousness, 
are experienced as significant and special. This special feel motivates those who experience them to tell people, and they usually do.

Sometimes, archetypes are expressed directly by the individuals who have them, as for example when a young child recounts a dream of ascension to a father, or when an artist or musician creates a piece of artwork with archetypal themes. We might call this type of expression primary expression because it is the individual who experienced the archetype that is interpreting and telling its story. Sometimes, however, other people get involved and "help" the person express, interpret, and tell the story. For example, the child who has an archetypal dream might tell their father who then tells a psychologist about the dream. The psychologist might then write an interpretation which, if published in a book, can reach many people over many generations. Or, a mystic might have an archetypal vision, or a series of archetypal visions. This mystic might talk about the archetypes, but then somebody else might come along and set down the visions in a book, Veda, Gatha, Bible, or scripture of some sort. We might call this type of expression secondary expression of archetypes, because the expression and interpretation of an archetype is taken over by an individual or institution without direct experience of the archetype.

Carl Jung refers to the expression and interpretation of archetypes, whether that is done in a primary or secondary fashion, as an elaboration. Although he is aware that elaboration can lead to something "entirely different" from the original experience (Jung 1980:9), it is not a critical 
awareness. There is no analysis of the processes which impinge on the expression of archetypes and turn them into something "entirely different." In the end, Jung simply accepts that if archetypes are elaborated, they are elaborated for positive purposes. This is the case even when large scale elite institutions like the Christian Church are involved. As he says, archetypes, especially when elaborated in Church dogma, help one mitigate powerful experiences of divinity that would otherwise overwhelm. "...the dogmatic image of divinity that had been developed over the centuries worked like a healing draught. It helped him to assimilate the fatal incursion of an archetypal image and so escape being torn asunder.” (Jung 1980:11)

Jung's positive assessment of elaboration is sociologically naive. Humans are imperfect, selfinterested, and often damaged by a toxic socialization process. As a consequence, bias and other factors enter into the elaboration, not only in the primary but also (and perhaps especially) in the secondary expression. Consider the ancient religious figure Zarathustra (a.k.a. Zoroaster). Zoroaster was a mystic who lived approximately 1,000 B.C.E. (Boyce 2001). Zoroaster had a series of visions the output of which became the Zoroastrian religious faith. Interestingly, Zoroaster appears to have dreamed many of the archetypes that we are familiar with today, like the struggle between light and dark forces, and the ideas of testing, punishment, judgment, reward, and so on. As Boyce (2001:1) notes, "Zoroastrianism is the oldest of the revealed creedal religions, and it has probably had more influence on mankind, directly and indirectly, than any other single faith" (Boyce, 2001: 1). 
Zoroaster's visions were considered special revelations, and his grass roots, anti-elite teachings (Messadie 1996) were passed on word of mouth for several centuries until finally, in and around C.E. 250, the Zoroastrian teachings and the archetypes which they contained were "elaborated" and written down into the Gathas, the sacred books of the Zoroastrian Faith. This elaboration and codification was conducted by a Sassanian high priest named Tanser, working under the authority of the Sassanian autocrat Ardashir. Tanser began the process of elaboration and codification when he declared Ardashir the final arbiter of the Zoroastrian doctrine. He claimed this authority for his regent by suggesting that Ardashir was "more richly endowed with virtues than the ancients..." Tanser further suggested that Ardashir was uniquely qualified to revive a faith that had "decayed" because he was a man of "true and upright judgment..." (Boyce 2001:102-3). Once the authority of Ardashir had been proclaimed, Tanser then selected a single Zoroastrian tradition among several that were available in the region, after which he brutally and with "excessive bloodshed" (Boyce 2001:103) sterilized the archetypal field by suppressing all other traditions.

"...in place of the former fraternity of regional communities, a single Zoroastrian church was created under the direct and authoritarian control of Persia; and together with this went the establishment of a single canon of Avestan text, approved and authorized by Tanser... Tanser set about his business and selected one tradition and left the rest out of the canon. And he issued this decree: The interpretation of all the 
teachings of the Mazda-worshipping religion is our responsibility." (Boyce 2001:103)

Why would the autocrat Ardashir claim interpretive superiority, reduce the Zoroastrian faith to a single cannon, and violently subdue competing understandings? The answer to these questions is simple. The grammar of Zoroastrian religious teachings were archetypes and archetypes are powerful. Ardashir used the Zoroastrian religion and the archetypes they contained as propaganda. He used them to consolidate power and gain domination over his enemies. He used them not for the good of humanity and not because he thought they reflected some neurological or spiritual truths, but to construct a discourse (McHoul and Grace 1993) that would help him create a world in his image by controlling how people saw themselves, saw the world, and how they acted in the world. According to Mary Boyce,

Ardashir was not only a military genius, but a man of great shrewdness and administrative talents, who was prepared to use bloodless means as well as warlike ones to establish his rule and create a new Persian empire; and one of the tools which he chose for this was religious propaganda. There can be little doubt that the priests of Persia, whose forefather had led to Zoroastrian community under the Achaemenians, felt themselves well fitted to do so again; and they plainly undertook with zeal the task of persuading their fellow Iranians that they, together with the new 
dynasty to which they lent their support, were more devout and orthodox, and would be truer upholders of the faith, than their Parthian predecessors had been. (Boyce 2001:101-2)

Ardashir and his high priest Tanser created what Ruyle referred to as an ideological institution. According to Ruyle (1975:11), ideological institutions are "special instruments of... thought control that are staffed and/or controlled by those who benefit from and therefore seek to, consciously and with considerable vigour, maintain systems that provide them with "special privileges and wealth." Walt Disney, Marvel Studios, and the Catholic Church are all ideological institutions. The example of Ardashir demonstrates exactly how elites create these "special instruments" as well as just how much vigour they use to create and maintain the system. The Persian high priest created a specific type of ideological institution, what we might call a Symbol Factory, or a factory where archetypes are captured, elaborated, produced, and distributed with a certain, usually elite, agenda in mind. This is certainly what Ardashir did. Ardashir claimed interpretive superiority, subdued competing interpretive communities, and organized the Zoroastrian faith under a single cannon created to serve his empire building agenda.

At this time, there are several open questions concerning how Ardashir used the Zoroastrian archetypes to create his new Persian empire. What elements of the Zoroastrian archetypes did he suppress when he consolidated the teachings? What elements of the Zoroastrian did he 
reinterpret? Did his reinterpretation of the archetypes provided by Zoroaster significantly alter them, perhaps even change their meaning? Who were these efforts aimed at? Were they aimed at other elites or the masses in general? Were his efforts successful? Did taking control and modifying an entire religion help him create the world that he envisioned?

Whatever the answer to these interesting questions is, it does not change the basic argument which is simply this: if we want to understand archetypes, we cannot simply look at the archetypes themselves, we also have to look at the people expressing the archetypes, their social class and gender positions, their economic interests, their biases, and so on. In other words, we have to look at motivation and purpose of specific interpretive communities, because that figures into the archetypes we receive and how we interpret them. Given Ardashir's goal of regional domination and his willingness to use archetypes and human spirituality as a tool in his conquest of the region, it is unlikely the archetypes we receive through the Zoroastrian Gathas, and which now penetrate Judaism, Islam, and even atheist popular culture, represent the archetypes as originally imagined by Zoroaster himself.

It is very difficult to gaze back thousands of years to the Zoroastrian faith to understand exactly what Tanser and Ardashir did to the Zoroastrian archetypes, how they reinterpreted and twisted them, and what meanings they discarded in the process. However, we do have a more recent example of how elites use archetypes for political and economic purposes. Our example here is 
the Western tarot deck. The tarot deck was originally a simple set of cards (Decker, Depaulis, and Dummett 1996; Decker and Dummett 2002). During the Industrial Revolution this simple deck of picture cards was picked up by an elite esoteric organization (Versluis 2007), Freemasonry. At the time, members of this organization consisted of landed nobility and emerging capitalist elites. These elites use the playing cards as a clay tablet upon which to inscribe a series of powerful archetypal answers to life's existential questions, answers intended to shape self image and action in a way that would facilitate the transition of power from feudal to capitalist agents (Sosteric 2014). We have already seen one example of a tarot archetype in the Fool card, which you will now understand as a Masonic elaboration of the hero archetype, but all the other major cards in the deck (like Wheel, Judgment, and so on) are archetypes as well. Unlike the Zoroastrian faith, we have a much better idea of exactly what the Freemasons did to the tarot. Basically, they borrowed the images from preexisting playing cards, used already existing archetypal elaborations common in esoteric circles, and provided commentary that constructed archetypal meanings for the individual cards. They then elevated their fabricated system of archetypes to the status of "sacred" via performance, as Ardashir did. In this process of selfinterested elaboration and production, they created what Decker, Depaulis, and Dummet (1996:27) suggested was the

...most successful propaganda campaign ever launched: not by a very long way the most important, but the most completely successful. An entire false history, and false 
interpretation, of the Tarot pack was concocted by the occultists; and it is all but universally believed."

The elite nature of the deck is not hard to determine. The deck itself in its various versions is shot through with images of wealth, privilege, hierarchy, authority, and submission. Esoteric commentators like Papus reflect and reinforce this hierarchy in their commentaries, as for example his suggestion that the symbolism of the cards represents a universal expression of the divine "truth" of the human caste structure.

These symbols correspond with the four great human castes. The men of Yod, or the Inventors, the Producers. The Nobility of Intellect. The men of $\mathrm{He}$, or the depositaries of the great truths discovered by the men of Yod: the Savants, the Judges. Professional nobility. The men of Vau, or the guardians and defenders of the former: the Warriors. Nobility of the sword. The men of the 2nd He, the multitude from which the other classes are continually recruited: the People.(Papus 1978)

In some versions of the tarot, as for example the Golden Dawn version of the Wheel card provided here, humanity is

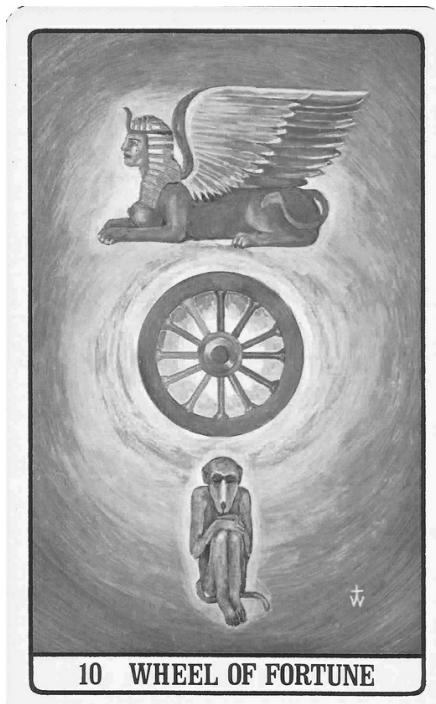


reduced to a two caste system, with elites at the top and the unwashed and passive masses below (Cicero and Cicero 1996:49)

More detail on the archetype created in the Freemason's symbol factor can be found in Sosteric (2014). Here it is enough to emphasize that the "spiritual" or esoteric tarot as provided by the Freemasons is a collection of archetypes created and deployed specifically for the purpose of supporting the development, spread, and maintenance of Capitalism, and the social class and gender inequalities upon which it depends. The use of the tarot to inscribe elite ideology reflects a wider process of archetypal elaboration, ideological formation, or discourse control that occurs when elites take elements of human imagination and human spirituality and exploit them for a specific purpose. This is hardly a new insight. Karl Marx, Michelle Foucault, and others have noted how concepts and ideas are located in structures of power and discourse designed to influence and control human behaviour. This article only points out that this interference extends into the arena of human psychological/spiritual experience. An ancient autocrat trying to build a new empire, a medieval Roman emperor seeking to maintain power in the face of Christian threats, and an emerging industrial elite needing to manage the transition from Feudalism to Capitalism (Sosteric 2014), or even commercially operated Hollywood studios are all symbol factories that exploit human imagination, archetypes, and human spiritual experience in order to create ideology, inscribe power, and support and reproduce the status quo. The culture industries of this planet trade in the repetitious elaboration and display of certain Capitalist friendly 
archetypes (or tropes), like the archetype of good versus evil (Star Wars, any Marvel Studios production) or the hero's journey to individualization, e.g., to becoming a "real boy" (e.g., Pinocchio/Disney).

\section{Contested Spirituality}

When examining archetypes from a sociological perspective, we can discern a four step process that archetypes can go through on their way to becoming established in the spiritual lexicon of a culture. Step one is the actual experience. Step two is the primary and secondary elaboration. Step three is the production of archetypes for wider distribution. Step four is the distribution of these archetypes to the intended consumer, i.e., the masses going to church or attending a Star Wars movie. In the case of the Zoroastrian archetypes, Zoroaster's individual experiences where elaborated both in community and later by elite Persian priests. These priest produced archetypes (i.e., they created the Zoroastrian sacred texts) and then distributed these archetypes in Persia. Later on, they were taken up by Western monotheisms and eventually the modern Capitalist culture industry (Sosteric Unpublished) .

Given that elites get involved in the elaboration and dissemination of archetypes, it is reasonable to suggest that archetypes themselves, and perhaps all aspects of human spirituality, operate in a contested space where actors exploit elements of religious discourse, like the bible, the tarot, etc., 
to provide meaning and moral (Nesbitt 2020) and political authority to support their vested interests. This contest can be framed as a contest between various actors seeking to further progressive or reactionary agendas. Margot Adler (1986) notes that Wiccan and Pagan spiritualities emerge as a consequence of disaffection with what members of these communities view as the oppressive traditions of Western Monotheism (Catholicism, Judaism, etc.). Pagan spiritualities like Wicca, which will also contain elaborated version of collective archetypes, are attempts to recover an authenticity lost in elite generated or elite infiltrated spiritual traditions. Archetypes may occupy a similarly contested space with authors and artists contesting and trying to recover authenticity lost when elite actors take control of the archetypes.

If true, we might find evidence of this contest in the various stages of archetypal production identified earlier. artistic renderings of Tarot decks, or in the artistic output of writers, musicians, painters, mystics, and others working to recover the "purity" of primary archetypal expression. We might also look for evidence of this contest in the suppression of "marginal knowledges" (McHoul and Grace 1993:15) i.e. knowledge systems that stand contrary to the mainstream provided by Western monotheistic religions. Consider for example the brutal repression of Australian aboriginal archetypal systems derived from "dreaming" or visions quests (Lawlor 1991; Some 1994) or the Catholic repression of African shamanic knowledge systems which undermine a capitalist world view. (Some 1994). 
Looking for evidence of a contested spirituality, telling the story of how archetypes are co-opted and marginal knowledges suppressed, is important. For sociologists it is important because it elaborates a fascinating area of inquiry traditionally neglected by sociologists who study religion and human spirituality. For psychologists, it is important because elite archetypes are often inadvertently accepted as deep spiritual/psychological wisdom and then used in therapeutic contexts where therapists then inadvertently and inappropriately use them to shape clients into forms suitable for insertion into the capitalist system. Telling this story is also important for human survival reasons as well. Over the years, scientists have noted the psychological, economic, and ecological disaster unfolding on this planet. They have recognized that science has played a part in this disaster by disenchanting the world and stripping it of deeper meaning and ritual. Unfortunately, it has not created “...new rituals to mark life's developmental stages; it has not found ways to fulfill people's needs for interpersonal intimacy or meaningful work, or their hunger for spiritual fulfillment through unity with a schema greater than themselves." (Krippner 1988:131). Since humans arguably have a need for this deeper meaning, this failure has left an ethical and archetypal vacuum that has allowed elite systems of meaning to dominate the human psyche. This is a vacuum that interested scholars should move to fill. Of course, in a discipline that prides itself on the arm's length distance it puts between itself and "savage superstition," as Berger (1970:24) one put it, this suggestion may strike some as anathema; however, concern for religious reform existed at the birth of sociology. August Comte, 
recognizing the limitations and abuses to which religion had been put through the years, tried to start a new "positive" religion (Comte 1852). Similarly, but somewhat less ambitious, scholars in other disciplines have called for a reenchantment of science (Griffen 1988) with discourses (Laszlo, Grof, and Russell 1999) and creation stories (Swimme 1988) that provide the deeper meaning humans require, and that would presumably offer an alternative to elite discourse. Given the ecological and political horrors unfolding as a consequence of unfettered Capitalism, horrors at least in part aided and abetted by archetypal systems created in elite symbol laboratories like the Sasanian high priest's temple or Freemason's lodge, this project is important. New archetypes, or at least new interpretations, have to be developed that take human consciousness away from meaning systems reflective of elite economic and political interest and towards more egalitarian, humanistic, and ecologically consciousness alternatives. Such a project would be stymied by failure to take into account elite manipulation of symbol systems. Failure to recognize that elites elaborate archetypes to support their specific agenda would inevitably mean importing these elite ideas into our attempts to break free. For example, Laszlo (2006) attempts to re-enchant science but imports archetypal notions of good and evil sourced, as we have seen, in the Persian Gathas created some 1,800 years ago by an elite actor bent on reshaping the world. Laszlo's language is secular, but the elite elaborated archetypes are recognizable just the same.

How do we start the re-enchantment of science? How do we imagine/create new archetypes that reflect goals and values other than those co-opted and created by elite actors? This will require at 
least three things. Number one, it will require an in depth historical, psychological, and sociological analysis of existing archetypal systems with specific attention paid to how archetypes are co-opted and elaborated by elites for political and economic purposes. Number two, it will require the careful elaboration of new archetypes conducive not to the Capitalist agenda, but to a humanistic or authentically spiritual one. Archetypes should not be used to support a predatory and destructive capitalist system that privileges a fortunate/chosen few while disadvantaging the many and threatening the planet. Archetypes should be used to support the creation of a world of prosperity, peace, harmony, and empowerment for all. Number three, it will require a concerted effort to produce and distribute the new archetypes. This production and distribution is critical, but has historically been something that only elites have had the resources to do. These days however, the Internet has democratized things a bit and cultural production has been diffused into the hands of non-elite actors.

We can approach the task of constructing new archetypes in one of two ways. Either we attempt to recover authenticity presumably lost when elites co-opt and elaborated our archetypal imaginings, as some suggest we do (Lawlor 1991), or we can break that link and develop fresh new systems and symbols. Probably, a combination of both will work best. Ancient belief systems may provide us with clues, but certainly they will have to be carefully translated and updated for the modern scientific mindset. For example, the elite generated archetype of good versus evil, an archetype which answers the big question "Why bad things happen in the world?" 
will have to go. This belief is anachronistic, superstitious, and dangerous. Not only does it support the Capitalist system, a system which is arguably destroying this planet, but it also a powerful idea that any tin-hat autocrat with a modicum of psychological sophistication can use to manipulate and exploit the masses (Sosteric 2018).

We can come up with existing, science-based, alternatives to archetypes colonized by elite actors. When we ask the question "Why do bad things happen in the world?" we can answer not because of some cosmic force and not because somebody made the "wrong" choice, but as consequence of a toxic socialization process that damages the mind and body and makes individuals prone to mental illness, violence, and addiction. Thus, a political actor like Donald Trump is not "evil" in the cosmic sense of the word. He is who he is because of the violence he experienced as a child, adolescent, and adult, which has left him with serious psychological and emotional impairments. This latter explanation for evil breaks free of elite bred archetypes which blame individual victims, thereby diverting attention from the true culprit which is a toxic Capitalism, and sources evil in psychological and social processes rooted in the oppressive experiences of life in a Capitalist system. This archetype provides an alternative view of self and the world that provides a reasonable and scientifically grounded path forward. If we want to understand and end evil, do not punish and condemn individuals; instead, transform Capitalism and heal the damage it has caused. 
This idea that bad human behaviour is caused not by evil but by a toxic socialization process that damages the human body and mind would also replace the idea that life is an individualistic fool/ hero's journey. Instead of viewing ourselves as fools here to learn life's lessons, we would see ourselves as victims of a toxic political and economic system. With this new archetype active, our goal would not be to learn our lessons or fight evil but rather to lift ourselves out of the toxic sludge and work with others to recreate the world. The rather more revolutionary idea that life is about reducing the violence of toxic socialization, healing the damage, and changing the world to prevent ongoing damage, is captured in two archetypal images from my own archetype deck, currently in development. These images show, on the one hand, an individual climbing out of the toxic sludge of an unhealthy socialization process and on the other twenty-four multi-colour figures representing the full gender/ethic/social class spectrum of humanity working together to improve the world. 

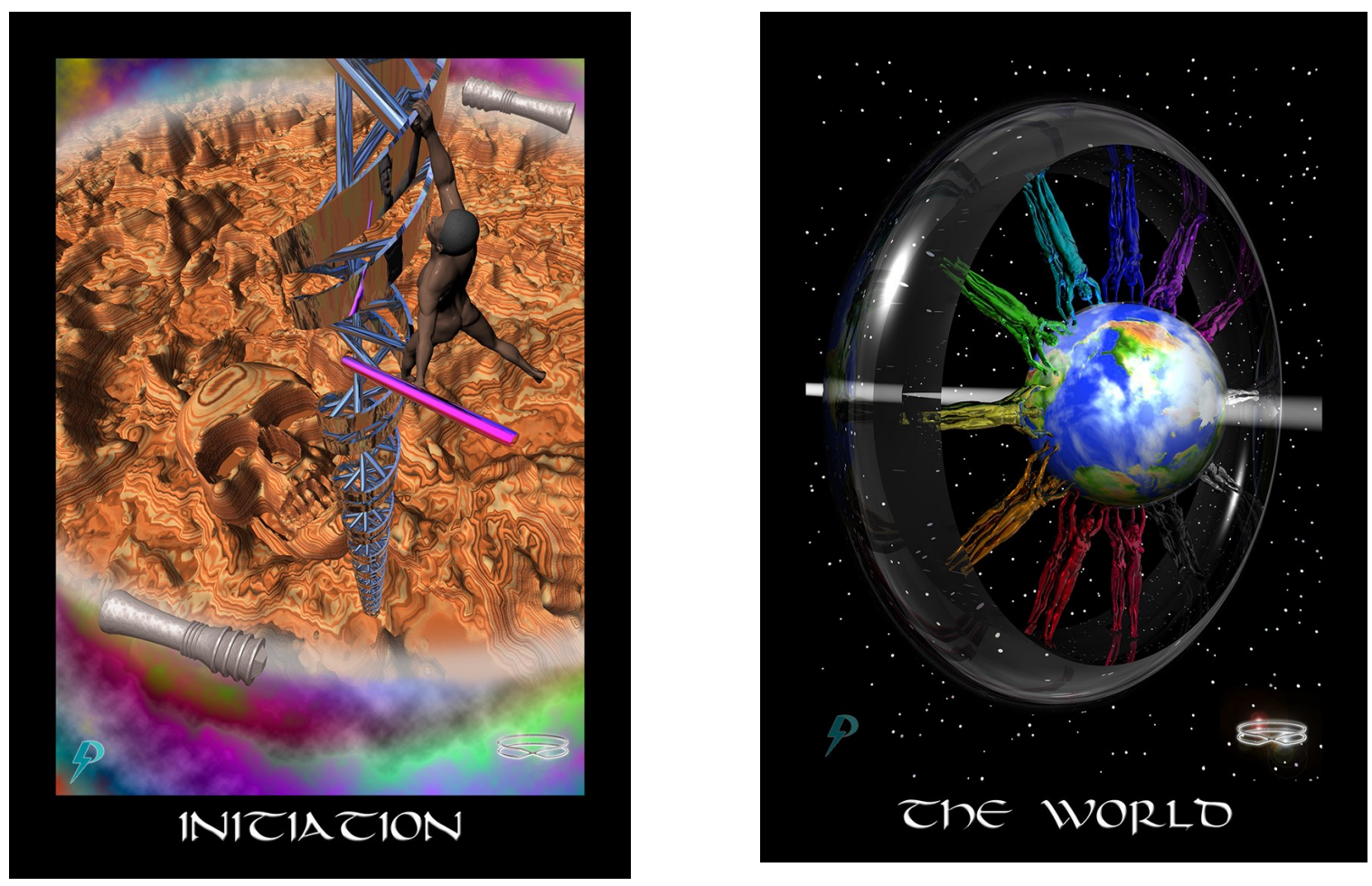

Archetypes like the above could be used to self consciously replace the dominant elite archetypes which have colonized our secular and religious worldviews. They could led to spiritual and religious belief systems that were more egalitarian and progressive, rather than the current systems which are hierarchical, authoritarian, destructive, and servants of the Capitalist system. 


\section{Conclusion}

In closing up this paper, I would like to note that nothing said here invalidates the neurological, cultural, political, or spiritual importance of archetypes. In fact, the paper underlines their importance. Not only does this paper acknowledge these archetypes as significant at a psychological level, it also points to the sociological, economic, and historical importance of archetypes and the need to develop a sociologically nuanced understanding of them. Sociological factors like social class, gender, and ethnicity figure into the expression, elaboration, production, and distribution of archetypes. Because archetypes significantly impact personal psychological development as well as personal and collective political and economic action, researchers need to understand these archetypes and the various sociological factors which impact their production and distribution.

To summarize, archetypes, whether experienced in dreaming, during meditation, as part of vision quests, or in powerful mystical experiences, and whether elaborated in a primary or secondary fashion, shape our views of self and influence our actions in the world. Archetypes are powerful and important; however, archetypes, sourced in human imagination have been co-opted and corrupted by elite actors who colonize these important experiences and shape them for their political or economic goals. The nature of these archetypes and the consequences of this colonization for human health and this planet's survival need to be carefully examined. In 
addition, these archetypes need to be replaced. As commentators have noted, science can and should play a role here. Unfortunately, science has disenchanted the world and left a vacuum that has allowed archetypes elaborated by elites total domination of the collective psyche. If science is to play a role, it must accept the significance of archetypes and self-consciously help develop alternatives rooted in the psychological, emotional, and sociological realities of human existence. The way forward here is the re-enchant of the world with new archetypes grounded not in the elite interests of the few, but in the humanitarian interests of humanity as a whole. Whether we look to ancient Indigenous systems of knowledge as some suggest we should (Lawlor 1991), develop entirely novel archetypal systems as suggested in this paper, or proceed forward with some combination of the two, is a choice we can make as we go forward 


\section{References}

Adler, Margot. 1986. Drawing Down the Moon: Witches, Druids, Goddess-Worshippers, and Other Pagans in America Today. Boston: Beacon Press.

Berger, Peter. 1970. A Rumor of Angels. New York: Anchor Books.

Boyce, Mary. 2001. Zoroastrians: Their Religious Beliefs and Practices. Routledge.

Brigit, Biddy. 2020. "Fool Tarot Card Meanings.” Biddy Tarot. Retrieved May 10, 2020 (https:// www.biddytarot.com/tarot-card-meanings/major-arcana/fool/).

Broker, Ignatia. 1983. Night Flying Woman: An Ojibway Narrative. Minnesota: Minnesota Historial Society Press.

Campbell, Joseph. 2008. The Hero with a Thousand Faces. Mumbai: Yogi Impressions.

Cicero, Chic, and Sandra Tabatha Cicero. 1996. The New Golden Dawn Ritual Tarot: Keys to the Rituals, Symbolism, Magic, and Divination. Minnesota: Llewellyn.

Comte, Auguste. 1852. The Catechism of Positivism; or, Summary Exposition of the Universal Religion. London: John Chapman.

Decker, Ronald, Thierry Depaulis, and Michael Dummett. 1996. A Wicked Pack of Cards: The Origins of the Occult Tarot. New York: St Martin's Press.

Decker, Ronald, and Michael Dummett. 2002. A History of the Occult Tarot, 1870-1970. London: Duckworth. 
Dossey, Larry. 2015. "Nonlocal Mind: A (Fairly) Brief History of the Term." Explore: The Journal of Science and Healing 11(2):89-101. doi: http://dx.doi.org/10.1016/j.explore.2014.12.001.

Ehrman, Bart D. 2007. Misquoting Jesus: The Story Behind Who Changed the Bible and Why. Harper One.

Ellens, J. Harold. 2001. "Introduction: The Destructive Power of Religion." Pp. 1-9 in The Destructive Power of Religion: Violence in Judaism, Christianity, and Islam, edited by J. H. Ellens. Westport, CT: Praegar.

Foucault, M. 1980. Power/Knowledge: Selected Interviews and Other Writings. London: Harvester Press.

Frederick Johnson. 1943. "Notes on Micmac Shamanism." Primitive Man 16(3/4):53. doi: $10.2307 / 3316279$.

Glass, Jennifer. 2019. "Why Aren't We Paying Attention?: Religion and Politics in Everyday Life." Sociology of Religion 80(1):9-27. doi: 10.1093/socrel/sry041.

Griffen, David Ray. 1988. "Introduction: The Reenchantment of Science." Pp. 1-46 in The Reenchantment of Science, edited by D. R. Griffen. New York: SUNY Press.

Harner, Michael. 2013. Cave and Cosmos: Shamanic Encounters with Another Reality. Berkeley, California: North Atlantic Books.

Jantzen, Grace M. 1995. Power, Gender, and Christian Mysticism. New York: Cambridge University Press.

Jayanti, Amber. 1988. Living the Tarot: Applying an Ancient Oracle to the Challenges of Modern Life. London: Wordsworth.

Julian of Norwich. 1901. Revelations of Divine Love. Christian Classics Ethereal Library. 
Jung, Carl. 1964. Man and His Symbols. New York: Anchor Press Double Day.

Jung, Carl G. 1980. The Archetypes and the Collective Unconscious. 2nd ed. edited by G. Adler, S. H. Read, M. Fordham, and W. McGuire. New York: Princeton University Press.

Krippner, Stanley. 1988. "Parapsychology and Postmodern Science." Pp. 129-40 in The Reenchantment of Science, edited by D. R. Griffen. New York: SUNY Press.

Laszlo, Ervin. 2006. Science and the Reenchantment of the Cosmos. Rochester, Vermont: Inner Traditions.

Laszlo, Ervin, Stanislav Grof, and Peter Russell. 1999. The Consciousness Revolution. Las Vegas: Elf Rock Productions.

Lawlor, Robert. 1991. Voices of the First Day: Awakening in the Aboridinal Dreamtime. Rochester, Vermont: Inner Traditions.

Marx, Karl. 1978. "The German Ideology.” in The Marx-Engels Reader, edited by R. Tucker. New York: Norton.

McHoul, Alec, and Wendy Grace. 1993. A Foucault Primer: Discourse, Power and the SUbject. New York: Routledge.

Messadie, Gerald. 1996. A History of the Devil. New York: Kodansha.

Metzner, Ralph. 1971. Maps of Consciousness: I Ching, Tantra, Tarot, Alchemy, Astrology, Actualism. New York: Collier Books.

Miller, William R. 2004. "The Phenomenon of Quantum Change." Journal of Clinical Psychology 60(5):453-60. doi: 10.1002/jclp.20000.

Mudrooroo. 1995. Us Mob: Australia: Angus \& Robertson. 
Nesbitt, Paula D. 2020. "Engaging Religion in a Contested Age: Contestations, Postmodernity, and Social Change." Sociology of Religion 81(2):142-57.

Papus. 1978. The Tarot of the Bohemians. Wilshire Book Co.

Perry, Samuel L. 2020. "The Bible as a Product of Cultural Power: The Case of Gender Ideology in the English Standard Version." Sociology of Religion 81(1):68-92. doi: 10.1093/socrel/ srz022.

Regardie, Israel. 2004. The Middle Pillar: The Balance Between Mind and Magic. St Paul, Minnesota: Llewellyn.

Ruyle, Eugene E. 1975. "Mode of Production and Mode of Exploitation: The Mechanical and the Dialectical.” Dialectical Anthropology 1(1):7-23. doi: 10.1007/bf00244565.

Semetsky, Inna. 2000. "When Cathy Was a Little Girl: The Healing Praxis of Tarot Images." International Journal of Children's Spirituality 15(1):59-72.

Smoley, Richard, and Jay Kinney. 2006. Hidden Wisdom: A Guide to Western Inner Traditions. Illinois: Quest Books.

Some, Malidoma Patrice. 1994. Of Water and the Spirit. New York: Penguin Arcana.

Sosteric, Mike. Unpublished. "From Zoroaster to Star Wars, Jesus to Marx: The Art, Science, and Technology of Human Manipulation.” Retrieved (https://www.academia.edu/34504691).

Sosteric, Mike. 2014. “A Sociology of Tarot.” Canadian Journal of Sociology 39(3).

Sosteric, Mike. 2018. "Star Wars Is a Religion That Primes Us for War and Violence." The Conversation. 
Swimme, Brian. 1988. "The Cosmic Creation Story." Pp. 47-56 in The Reenchantment of Science, edited by D. R. Griffin. New York: State University of New York.

Vaillant, George E. 2002. "Quantum Change: When Epiphanies and Sudden Insights Transform Ordinary Lives." American Journal of Psychiatry: Official Journal of the American Psychiatric Association (9):1620. doi: 10.1176/appi.ajp.159.9.1620.

Vaughn, David Becker, and Steven L. Neuberg. 2019. "Archetypes Reconsidered as Emergent Outcomes of Cognitive Complexity and Evolved Motivational Systems." Psychological Inquiry 30(2):59-75.

Versluis, Arthur. 2007. Magic and Mysticism: An Introduction to Western Esotericism. Maryland: Rowman and Littlefield. 